
\title{
$\angle$ Research Square \\ Factor VII Deficiency and Pregnancy: A Case Report and Review of Literature
}

\section{Minakshi Rohilla}

PGIMER: Post Graduate Institute of Medical Education and Research

Rakhi Rai ( $\nabla$ drrakhi81@yahoo.co.in )

AllMS: All India Institute of Medical Sciences https://orcid.org/0000-0002-8208-4126

Jasmina Ahluwalia

PGIMER: Post Graduate Institute of Medical Education and Research

\section{Pankaj Malhotra}

Post Graduate Institute of Medical Education and Research

\section{Vanita Jain}

Post Graduate Institute of Medical Education and Research

\section{Research Article}

Keywords: Factor VII, coagulation, haemorrhage, pregnancy, prothrombin time, activated partial thromboplastin time

Posted Date: May 11th, 2021

DOI: https://doi.org/10.21203/rs.3.rs-502009/v1

License: @ (i) This work is licensed under a Creative Commons Attribution 4.0 International License. Read Full License

Version of Record: A version of this preprint was published at SN Comprehensive Clinical Medicine on October 19th, 2021. See the published version at https://doi.org/10.1007/s42399-021-01037-5. 


\section{Abstract}

Inherited factor VII deficiency is an autosomal recessive coagulation disorder with broad range of bleeding manifestations. The association between bleeding and absolute factor VII level is poor. Usually, the bleeding is associated with FVII levels of less than $1 \%$ of the normal value. Factor VII deficiency is associated with prolongation of prothrombin time only with normal activated partial thromboplastin time. Approximately 66 pregnant women have been reported with factor VII deficiency so far in English literature. We hereby, report 2 cases along with the review of literature of Factor VII deficiency during pregnancy. Our patients were diagnosed to have factor VII deficiency after deranged coagulogram with factor VII level of < $1 \%$ and $17.1 \%$ respectively, however could be managed by fresh frozen plasma only in first case and fresh frozen plasma \& factor VII concentrate in second case successfully. Coagulogram is a simple, easily available, affordable and lifesaving investigation to detect this deficiency in pregnancy.

\section{Introduction}

Inherited factor VII (FVII) deficiency is a rare coagulation disorder, prevalence being 1:300 000 to 1:500 000 $[1,2]$ of severe form and 1 in 350 for heterozygotes [3].

FVII deficiency, autosomal recessive disorder, is associated with different bleeding manifestations varying from minimal to life threatening haemorrhage. The usual clinical presentation is bleeding into joints \& muscles, excessive bruising, epistaxis and menorrhagia. There is a somewhat poor association between bleeding tendency and absolute FVII level; scanty symptoms may occur in those with very low FVII levels, whereas those with higher levels may present with significant bleeding [4] making it difficult to identify which patients will require prophylactic replacement therapy prior to hemostatic challenges or surgical intervention [5]. FVII deficiency in reproductive age women can manifest as menorrhagia, metrorrhagia, excessive bleeding after abortion and antepartum or postpartum hemorrhage $[3,6]$. Those with less than $1 \%$ FVII activity usually suffer from severe bleeding disorder similar to hemophilia [7]. FVII deficiency should be suspected in all women with history of bleeding and prolonged prothrombin time (PT) with normal activated partial thromboplastin time (APTT) [8]. Approximately 66 pregnant women (Table 1) have been reported with FVII deficiency $[5,9,7,8]$ so far. We hereby, report 2 cases of pregnancy with FVII deficiency along with review of literature. 
Table 1

Review of literature of 68 pregnant women with FVII deficiency

\begin{tabular}{|c|c|c|c|c|c|c|c|}
\hline Author & Year & $\begin{array}{l}\text { No of } \\
\text { women }\end{array}$ & $\begin{array}{l}\text { FVII } \\
\text { level }\end{array}$ & $\begin{array}{l}\text { Clinical } \\
\text { presentation } \\
\text { at diagnosis }\end{array}$ & $\begin{array}{l}\text { Mode of } \\
\text { delivery }\end{array}$ & APH/PPH & Prophylaxis \\
\hline $\begin{array}{l}\text { Kreuziger } \\
\text { et al [5] }\end{array}$ & 2013 & 62 & $\begin{array}{l}\text { Median } \\
-5.5 \%\end{array}$ & variable & $\begin{array}{l}53 \\
\text { vaginal, } \\
31 \\
\text { caesarean }\end{array}$ & $\begin{array}{l}\mathrm{PPH} \text { in } 10 \% \\
\text { with } \\
\text { prophylaxis, } \\
15 \% \\
\text { without } \\
\text { prophylaxis }\end{array}$ & rFVIla-FFP \\
\hline $\begin{array}{l}\text { Yazicioglu } \\
\text { [9] }\end{array}$ & 2013 & 1 & $\begin{array}{l}35- \\
46 \%\end{array}$ & $\begin{array}{l}\text { Abruptio } \\
\text { placentae at } \\
29 \text { wks } \\
\text { gestation }\end{array}$ & $\begin{array}{l}\text { Caesarean } \\
\text { section }\end{array}$ & $\mathrm{APH}$ & \\
\hline \multirow{2}{*}{$\begin{array}{l}\text { Das D et } \\
\text { al [7] }\end{array}$} & \multirow[t]{2}{*}{2014} & \multirow[t]{2}{*}{1} & \multirow[t]{2}{*}{$2 \mathrm{lU} / \mathrm{dl}$} & \multirow{2}{*}{$\begin{array}{l}\text { Menorrhagia, } \\
\text { epistaxis }\end{array}$} & \multirow[t]{2}{*}{ V.D } & \multirow[t]{2}{*}{ None } & $\mathrm{rFVII}$ \\
\hline & & & & & & & $\begin{array}{l}\text { Oral } \\
\text { tranexamic } \\
\text { acid }\end{array}$ \\
\hline $\begin{array}{l}\text { Lee YJ et } \\
\text { al [8] }\end{array}$ & 2014 & 1 & $\begin{array}{l}1.5- \\
11 \%\end{array}$ & $\begin{array}{l}\text { Prolonged } \\
\text { bleeding at } \\
\text { dental } \\
\text { extraction }\end{array}$ & C.S & None & $\begin{array}{l}\text { FFP, } \\
\text { tranexamic } \\
\text { acid, } \\
\text { vitamin } \mathrm{K}\end{array}$ \\
\hline $\begin{array}{l}\text { Pinar HU } \\
\text { et al [18] }\end{array}$ & 2015 & 1 & $1 \%$ & $\begin{array}{l}\text { Known case } \\
\text { of FVII } \\
\text { deficiency }\end{array}$ & $\begin{array}{l}\text { Dilatation } \\
\text { and } \\
\text { curettage } \\
\text { at } 9 \text { weeks } \\
\text { POG }\end{array}$ & None & \\
\hline \multirow[t]{2}{*}{$\begin{array}{l}\text { Current } \\
\text { study }\end{array}$} & 2016 & 1 & $<1 \%$ & $\begin{array}{l}\text { During routine } \\
\text { investigations, } \\
\text { previous } \\
\text { history of PPH }\end{array}$ & VD & $\begin{array}{l}\text { PPH in } \\
\text { previous } \\
\text { pregnancy }\end{array}$ & FFP \\
\hline & 2018 & 1 & $17.1 \%$ & $\begin{array}{l}\text { Antepartum } \\
\text { haemorrhage }\end{array}$ & $\begin{array}{l}\text { Lower } \\
\text { segment } \\
\text { caesarean } \\
\text { section }\end{array}$ & APH & FFPs/FVII \\
\hline
\end{tabular}

\section{Case Report 1}

A 32 years old second gravida, referred in view of deranged coagulogram, at term gestation. She was diagnosed as chronic hypertension since 16 weeks period of gestation (POG) and her blood pressure was well controlled on minimal dose of labetolol. Antenatal period was uncomplicated till 37 weeks POG when coagulogram showed prolonged PT of 100 seconds (control 13 seconds) and normal APTT of (control: 25-32 seconds) 26 to 28 seconds on several occasions. She revealed history of gum bleeding for last one month while brushing teeth otherwise there was no history of menorrhagia, epistaxis, petechiae, joint swelling or other bleeding manifestations. There was no history of bleeding disorders or consanguineous 
marriage in the family. During last delivery; she had history of traumatic postpartum hemorrhage (PPH), which was managed conservatively with vaginal packing and blood products. The liver function tests (LFTs) were normal. Her factor VII level found to be less than $1 \%$ and hence, diagnosis of FVII deficiency was reached. Six units of fresh frozen plasma (FFP) and two vials $(2.4 \mathrm{mg})$ of recombinant FVII were arranged and induction of labour was done with oxytocin at 37 weeks 3 days POG in view of increased blood pressure records. She delivered vaginally live born baby of $2.6 \mathrm{~kg}$ with Apgar score of 8, 9 . Prophylactically two units of FFP were transfused intrapartum. There was no intrapartum or postpartum hemorrhage. Both mother and baby were discharged on day 3 postpartum in a satisfactory condition. Factor VII level was confirmed after delivery and were found to be the same at 3 months post-delivery. Her siblings were also advised for screening for factor 7 deficiency.

\section{CASE REPORT 2}

27 years old primigravida came at 36 weeks POG with multiple episodes of vaginal bleeding from 32 weeks POG. During investigation, her prothrombin time was found to be prolonged 20 seconds, prothrombin index $62 \%$ with normal APTT of 28 seconds. LFT was within normal limits and serum level of FVII was found to be $17.1 \%$. There was no history of excessive bruising or bleeding from any other site of body. She was transfused FFPs and 1 unit of FVII preoperatively and taken up for caesarean section (C.S) in view of placenta previa. She delivered live born boy of $2.8 \mathrm{~kg}$ with Apgar score of 8,9 . There was no history of any intrapartum or postpartum complication. No blood or FFP transfusions were required intraoperatively. Both mother and baby were discharged in a satisfactory condition.

\section{Discussion}

FVII has a pivotal role in coagulation in vivo. Vascular injury leads to binding of FVII to Tissue Factor (TF), initiating coagulation and generating a concentration of thrombin at the place of vascular damage [10].

FVII deficiency was first recognized in 1951 by Alexander [11]. Patients with heterozygous genotype are typically asymptomatic whereas homozygous or compound heterozygotes develop bleeding manifestations. FVII levels are generally less than $10 \%$ of the normal values in homozygous or double heterozygous carriers in inherited FVII deficiency however may be approximately $20-60 \%$ in heterozygous carriers [5]. FVII level was less than $1 \%$ in first \& $17.1 \%$ in second case with no haemorrhagic manifestations following delivery. FVII deficiency may be seen in chronic liver disease, warfarin users, vitamin $\mathrm{K}$ deficiency secondary to long term antibiotic use, bile duct obstruction or poor intestinal absorption [8]. FVII deficiency was probably congenital, since no other aetiology was apparent in present cases which were managed with FFPs and FVII concentrates.

In reported cases, PT and APTT were performed multiple times as was done in our cases also and each time PT was prolonged and APTT was normal and hence, a deficiency of factor VII was suspected.

Women with heterozygous FVII deficiency have significantly higher FVII levels [6] with insignificant increase in FVII levels during pregnancy in women with homozygous (severe) FVII deficiency [12-15]. The risk of 
bleeding might be more in early pregnancy as compared to at term because of insufficient rise in FVII levels in early pregnancy [6]. In our cases, FVII level was estimated at term or near-term gestation with very low levels. This suggests that probably these patients were homozygous or double heterozygous for a mutation in the FVII gene.

Management of inherited FVII deficiency includes replacement therapy with FFPs, factor VII concentrates, prothrombin complex concentrates, and/ or recombinant F VIla (rFVIla) [1]. Previous bleeding episodes, recent FVII levels, mode of delivery and anticipated surgical intervention determine the decision about the treatment [5]. Despite a poor correlation of low FVII levels, the most serious bleeding has been linked with postpartum hemorrhage (PPH) and surgery $[7,16]$. Disadvantages of FFP are volume overload and the possibility of blood-borne infections. The treatment of choice is recombinant factor Vlla; however, the major issue with factor VII concentrate is a risk of disseminated intravascular coagulation and thromboembolic complications [17]. As our first case had a history of postpartum hemorrhage in previous pregnancy and had severe FVII deficiency in index pregnancy, 2 units of rFVIla were arranged but could be managed with FFPs. Prolonged second stage of labour and instrumental delivery which increases the risk of neonatal hemorrhage should be avoided [3].

66 pregnant women have been reported so far with factor VII deficiency $[5,7,8,9]$. The median FVII activity was $5.5 \%$. $76 \%$ women had level less than $10 \%$ and $82 \%$ had level less than $20 \%$. Similar FVII level were found in women with or without a history of bleeding. Hemostatic prophylaxis was used in 30 deliveries with recombinant FVII in 17 deliveries, FFP and FVII concentrate in 6 deliveries each and both FVII concentrate and FFP in one delivery [5]. Similar to first index case, case series included 8 women with FVII level $<1 \% .5$ women were delivered vaginally and 3 by C.S. All 3 women who had cesarean sections, received $\mathrm{rFVIla}$ as prophylaxis and in vaginal delivery group, one woman received FFP. Out of these eight patients, one had postpartum hemorrhage during cesarean despite receiving rFVIla [11]. Rate of hemorrhage was similar in the women who received prophylaxis and those who didn't. Hence, hemostatic prophylaxis is not necessary in all cases and should be individualized [5]. Yazicioglu et al [9] reported a case of FVII deficiency presenting as abruptio placentae at 29 weeks POG and was managed without any replacement therapy. Similar to first case, recently a case report of pregnancy in a known patient of FVII deficiency was successfully managed with antifibrinolytics and FFPs [8]. Pinar HU et al reported dilatation and curettage at 9 weeks POG in a patient with FVII deficiency after prophylactic administration of FVII [18].

Prenatal diagnosis should be offered to parents by Chorionic villus sampling/ amniocentesis/ cordocentesis to those parents who had severely affected child or when both parents are heterozygous carriers. Physiologically low levels in newborn make it difficult to diagnose FVII deficiency in neonatal period but FVII levels should be determined from cord blood at time of delivery if severe deficiency is suspected [3].

\section{Conclusion}


Considering the rarity of FVII deficiency, obstetrician needs to have a very high index of suspicion to identify these cases and prevent morbidity. Coagulogram is a simple, easily available and affordable investigation which can easily detect these cases and save lives. Replacement therapy and hemostatic prophylaxis is not necessary in all cases and should be individualized depending upon the factor VII levels and previous bleeding manifestations. Appropriate counselling of the mother regarding possibility of antenatal complications plays an integral part of continuation of such pregnancies.

\section{Patient Perspective}

We were satisfied with the management. We were not aware of the FVII deficiency. The diagnosis will help us in planning future pregnancies. We will be more careful in our day-to-day activities to prevent any injury.

\section{Declarations}

Funding (information that explains whether and by whom the research was supported) - No funding involved

Conflicts of interest/Competing interests (include appropriate disclosures) All the authors declare that they have no conflict of interest.

Ethics approval (include appropriate approvals or waivers) - Not applicable

Consent to participate (include appropriate statements) - Consent was taken from the patients.

Consent for publication (include appropriate statements)- Consent was taken from the patients.

Availability of data and material (data transparency) - Yes

Code availability (software application or custom code)- Not applicable

\section{Authors' contributions}

Minakshi Rohilla - 1) Substantial contributions to conception and design, acquisition of data, or analysis and interpretation of data; 2) Drafted and revised the article critically for important intellectual content; and 3) final approval of the version to be published.

Rakhi Rai - 1) Substantial contributions to conception and design, acquisition of data, or analysis and interpretation of data; 2) Drafted and Revised the article critically for important intellectual content; and 3) final approval of the version to be published.

Jasmina Ahluwalia - 1) Substantial contributions to conception and design, analysis and interpretation of data; 2) Revised the article critically for important intellectual content; and 3) final approval of the version to be published.

Dr Pankaj Malhotra - 1) Substantial contributions to conception and design, analysis and interpretation of data; 2) Revised the article critically for important intellectual content; and 3) final approval of the version 
to be published.

Dr.Vanita Jain - 1) Substantial contributions to conception and design, analysis and interpretation of data;

2) Revised the article critically for important intellectual content; and 3) final approval of the version to be published.

\section{References}

1. Perry DJ. Factor VII deficiency. Br J Haematol. 2002;118:689-700.

2. Mannucci PM, Duga S, Peyvandi F. Recessively inherited coagulation disorders. Blood. 2004; 104:1243-52.

3. Pike GN, Bolton Maggs PHB. Factor deficiencies in Pregnancy. Hemat Oncol Clin N Am. 2011;25:35978.

4. Bolton-Maggs PH, Perry DJ, Chalmers EA, Parapia LA, Wilde JT, Williams MD, Collins PW, Kitchen S, Bolan G, Mumford AD. The rare coagulation disorders - review with guidelines for management from the United Kingdom Haemophilia Centre Doctors' Organisation. Haemophilia. 2004;10:593-628.

5. Baumann Kreuziger LM, Morton CT, Reding MT. Is prophylaxis required for delivery in women with factor VII deficiency? Haemophilia. 2013;19:827-32.

6. Kulkarni AA, Lee CA, Kadir RA. Pregnancy in women with congenital factor VII deficiency. Haemophilia. 2006;12:413-6.

7. Das D, Ciantar E. (2014) Factor VII Deficiency in Pregnancy and Labour: A Case Report. Obstet Gynecol Int J 1[1]:00003.

8. Lee YJ, Ju DH, Yi SW, Lee SS, Sohan WS. Successful Management of maternal Factor VII Deficiency in a cesarean section. Obstet Gynecol Sci. 2014;57(4):314-7.

9. Yazicioglu A, Turgal M, Boyraz G, Yucel OS, Tarakan A, Ozyuncu O, Beksac S. Factor VII Deficiency During Pregnancy. J Turk Soc Obstet Gynecol. 2013;10:114-7.

10. Wildgoose P, Nemerson Y, Hansen LL, Nielsen FE, Glazer S, Hedner U. Measurement of basal levels of factor VIla in hemophilia A and B patients. Blood. 1992;80:25-8.

11. Alexander B, Goldstein R, Landwehr G, Cook CD. Congenital SPCA deficiency: A hitherto unrecognized coagulation defect with hemorrhage rectified by serum and serum fractions. J Clin Invest. 1951;30:596-608.

12. Rizk DE, Castella A, Shaheen H, Deb P. Factor VII deficiency detected in pregnancy: a case report. Am J Perinatol. 1999;16:223-6.

13. Robertson LE, Wasserstrum N, Banez E, Vasquez M, Sears DA. Hereditary factor VII deficiency in pregnancy: peripartum treatment with factor VII concentrate. Am J Hematol. 1992;40:38-41.

14. Braun MW, Triplett DA. Case Report: Factor VII deficiency in an obstetrical patient. J Indian State Med Assoc. 1979;72:900-2.

15. Eskandari N, Feldman N, Greenspoon JS. Factor VII deficiency in pregnancy treated with recombinant factor Vlla. Obstet Gynecol. 2002;99:935-7. 
16. Brummel Ziedins K, Rivard GE, Pouliot RL, Butenas S, Gissel M, Parhami-Seren B, et al. Factor VIla replacement therapy in factor VII deficiency. J ThrombHaemost. 2004;2:1735-44.

17. Guidelines on the selection. and use of therapeutic products to treat haemophilia and other hereditary bleeding disorders. Haemophilia. 2003;9:1-23.

18. Pinar HU, Basaran B, Dogan R. (2015) Use of low-dose recombinant factor Vlla in a pregnant patient with factor VII deficiency undergoing a minor surgery. J Obstet Anaesth Crit Care [cited 2019 Jun 13];5:37 - 8.

\section{Supplementary Files}

This is a list of supplementary files associated with this preprint. Click to download.

- CAREchecklistEnglish2013.docx 